\title{
ANALISIS PENERIMAAN SIMPUS DITINJAU DARI PERSEPSI PENGGUNA DI PUSKESMAS MOJOAGUNG DENGAN METODE TAM
}

\author{
Mochammad Choirur Roziqin', Demiawan Rachmatta Putro Mudiono², Nuril Amalia*3 \\ 1,2,3 Politeknik Negeri Jember \\ Email: ${ }^{1}$ irul@polije.ac.id, ${ }^{2}$ demiawanrpm@gmail.com, ${ }^{3}$ nurilamalia9a@gmail.com \\ *Penulis Korespondensi
}

(Naskah masuk: 12 Desember 2019, diterima untuk diterbitkan: 01 Februari 2021)

\begin{abstract}
Abstrak
Puskesmas Mojoagung telah menggunakan Sistem Informasi Manajemen Puskesmas (SIMPUS) hingga saat ini, akan tetapi dalam penggunaanya masih sering terdapat keluhan dari beberapa pengguna SIMPUS yang merasa tidak puas dengan SIMPUS yang telah berjalan, hal tersebut dapat dilihat dari ketidakpercayaan pengguna terhadap data pasien yang dihasilkan SIMPUS. Penelitian ini memiliki tujuan untuk melakukan analisis terhadap penerimaan SIMPUS ditinjau dari persepsi pengguna di Puskesmas Mojoagung dengan menggunakan metode Technology Acceptance Model (TAM). Jenis penelitian yaitu analitik kuantitatif dengan pendekatan cross sectional. Jumlah sampel yaitu seluruh pengguna SIMPUS di Puskesmas Mojoagung berjumlah 33 orang. Metode pengumpulan data menggunakan kuesioner guna memperoleh informasi mengenai persepsi pengguna SIMPUS. Tahap penelitian dimulai dengan mengidentifikasi masalah yang ada pada SIMPUS di Puskesmas Mojoagung, lalu penyusunan instrument yaitu kuesioner yang selanjutnya disebarkan ke responden sebagai pengambilan data dan yang terakhir menganalisis data sehingga menjadi kesimpulan. Hasil dari penelitian ini adalah terdapat hubungan yang signifikan antara variabel Perceived Usefulness dengan Acceptance of IT atau Penerimaan Sistem di Puskesmas Mojoagung dengan nilai signifikansi lebih kecil dari p-value (Sig.) yaitu 0.031 yang. Begitu juga dengan variabel Perceived Easy Of Use terdapat hubungan yang signifikan dengan Acceptance of IT atau Penerimaan Sistem di Puskesmas Mojoagung yang meiliki nilai signifikansi lebih kecil dari p-value (Sig.) yaitu 0.012. Sehingga dapat diartikan bahwa penerimaan SIMPUS di Puskesmas Mojoagung memiliki hubungan yang signifikansi terhadap persepsi kemanfaatan dan kemudahan penggunanya.
\end{abstract}

Kata kunci: Pusat Kesehatan Masyarakat, Sistem Informasi Manajemen Puskesmas, TAM

\section{ANAL YSIS OF SIMPUS ACCEPTANCE REVIEWED BY USER PERCEPTION IN PUBLIC HEALTH CENTER USING TAM METHOD}

\begin{abstract}
Mojoagung Public Health Center had been using Public Health Center Management Information System (SIMPUS) until now, but in application there are still many complaints from several SIMPUS users who are dissatisfied with the system has been running, it can be seen from the user's mistrust of the data that exist in SIMPUS. The purpose of this research are to analize and identify the success of SIMPUS in terms of user perceptions at the Mojoagung Public Health Center by using TAM method. The type of the research is quantitative analytic with cross sectional approach. Sample were all of SIMPUS users at the Mojoagung Public Health Center there are 33 users. The methods to collect data in this research used a questionnaire to obtain information about the perception of SIMPUS users. The research started identifying problem of SIMPUS at the Mojoagung Public Health Center and then composition of instrument is questionnaire that subsequently disseminated to respondents as data retrieval and the last analyzed data to conclusion. Result of the research are significant correlation between the variable Perceived Usefulness with Acceptance of IT at Mojoagung Public Health Center with significance values is smaller than p-value (Sig.) of 0.031, as well as variable Perceived Easy Of Use is significant correlation with Acceptance of IT with significance value is smaller than p-value (Sig.) of 0.012. So it can be interpreted that the acceptance SIMPUS at the Mojoagung Public Health Center has a significant relationship to the perception of the benefits and convenience of its users.
\end{abstract}

Keywords: Public Health Center, Public Health Center Management Information System, TAM 


\section{PENDAHULUAN}

Pusat Kesehatan Masyarakat tentunya memerlukan adanya sistem informasi yang baik dalam setiap pelaksanaan kegiatannya. Pernyataan tersebut di dukung dengan Kemenkes (2014) yang menyebutkan bahwasannya Sistem Informasi Kesehatan adalah suatu tatanan yang membantu mencapai sasaran kegiatan berdasarkan informasi yang tersedia. Selain itu, Sistem Informasi Kesehatan dapat memberikan pelayanan kesehatan di puskesmas berdasarkan informasi yang didapat dan berguna untuk menunjang proses fungsifungsi manajemen yang ada dan kebijakan secara cepat, tepat dan akurat (Kemenkes, 2014).

Manajemen yang dikatakan efektif dan efiesien memerlukan informasi, ketersediaan informasi di puskesmas diperoleh dari Sistem Informasi Manajemen yang berbasis pelayanan puskesmas. Terkait hal ini kementerian kesehatan mengeluarkan kebijakan seperti yang tertuang dalam Kemenkes (2014) bahwasannya untuk tercapainya berbagai upaya kesehatan perorangan dan upaya kesehatan masyarakat yang sesuai atas azas penyelenggaraan puskesmas, perlu ditunjang oleh manajemen puskesmas yang baik. Salah satu manajemen puskesmas tersebut yaitu Sistem Informasi Manajemen Puskesmas (SIMPUS).

SIMPUS adalah suatu Aplikasi Manajemen Puskesmas yang fungsi utamanya mengolah data pasien mulai dari pendaftaran sampai dengan pelaporan. Data yang telah diinputkan ditampung dalam sebuah data base yang nantinya dikatagorikan sesuai dengan parameter untuk kebutuhan laporan, seperti data kesakitan, laporan kunjungan harian, laporan persediaan obat serta laporan lainnya yang diperlukan dalam manajemen puskesmas (Thenu, Sediyono and Purnami, 2016).

Puskesmas Mojoagung merupakan puskesmas rawat inap tipe utama yang telah menerapkan SIMPUS hingga saat ini, pelaksanaan SIMPUS tersebut sudah terintegrasi mulai dari awal pelayanan berupa pendaftaran sampai dengan akhir pelayanan yaitu pelaporan serta telah terintegrasi dengan BPJS. Adanya sistem informasi ini sangat diharapkan dapat memaksimalkan proses pelayanan kesehatan. Implementasi SIMPUS pada Puskesmas Mojoagung dimulai dari data sosial pasien, data medis atau pelayanan yang diberikan kepada pasien yang kesemuanya dilakukan penginputan ke komputer.

Analisis sistem perlu dilakukan karena banyaknya keluhan pengguna terhadap sistem informasi puskesmas dikarenakan pengguna merasa kemampuan komunikasi data keluaran dari sistem kurang akurat dan komplit serta outputyang dihasilkan SIMPUS masih terjadi duplikasi pada identitas pasien yang mengakibatkan petugas harus mencocokkan data dahulu dengan data sekarang untuk mengubah data pasien yang benar. Permasalahan lain yang ditemukan pada sistem belum dapat memenuhi kebutuhan laporan Puskesmas, sehinga mengharuskan petugas membuat laporan secara manual. Keadaan ini didukung oleh tidak mampunya SIMPUS mencetak secara langsung form pendaftaran pasien baru, sehingga petugas harus menyalin data diri pasien pada form pendaftaran yang tersedia dan mencetaknya pada komputer lain. Selain hal tersebut SIMPUS masih sering terjadi error yang diakibatkan oleh jaringan sehingga tidak bisa berjalan, karena SIMPUS di Puskesmas Mojoagung adalah berbasis aplikasi. Serta dalam hal keamanan SIMPUS hanya memiliki satu username dan password yang di gunakan di Puskesmas Mojoagung sehingga tingkat keamanannya kecil. Selain permasalahan diatas, SIMPUS Mojoagung juga dapat menyimpan data pasien meskipun data tersebut belum terisi yang mengakibatkan terjadinya duplikasi data. Permasalahan selanjutnya yaitu, tidak terdapat menu "Bantuan" atau panduan dari SIMPUS pada aplikasi untuk memudahkan pengguna dalam menggunakan SIMPUS jika terjadi masalah. Selain itu Puskesmas masih mengandalkan kertas dalam operasionalnya dikarenkaan data pada berkas rekam medis lebih lengkap dibandingkan dengan SIMPUS.

Wawancara yang dilakukan peneliti kepada kepala rekam medis, bahwa sering terdapat keluhan dari beberapa pengguna sistem informasi puskesmas yang merasa tidak puas dengan apa yang sistem jalannkan, ketidakpuasan beberapa pengguna tersebut terlihat dengan ketidakpercayaan pengguna terhadap data yang dihasilkan oleh sistem. Penggunaan komputer dalam setiap kegiatan pelayanan terhadap pasien yang sudah berjalan hendaknya terus ditingkatkan dan perlu dilakukan pemantauan serta analisis. Secara bertahap petugas puskesmas mempelajari SIMPUS untuk terus meningkatkan kualitas pelayanan sistem kepada pasien.

Permasalahan yang telah disebutkan diatas merupakan alasan peneliti bahwa SIMPUS di Puskesmas Mojoagung perlu dilakukan analisis penerimaan terhadap persepsi pengguna. Pentingnya analisis penerimaan sistem menurut persepsi pengguna dikarenakan pengguna yang merasakan kebutuhan dan manfaat dari sistem.

Metode penelitian yang digunakan yaitu analitik kuantitatif dengan pendekatan cross sectional. Pada tahap awal peneliti melakukan identifikasi masalah yang ada pada SIMPUS di Puskesmas mojoagung. Masalah yang telah di identifikasi dibuat patokan untuk menyusun instrumen penelitian menggunakan kuesioner. Kuersioner tersebut akan dibagikan kepada seluruh pengguna SIMPUS di Puskesmas Mojoagung yang berjumlah 33 orang. Selanjutnya, setelah kuuesioner disusun dan disebarkan maka dilakukan 
pengambilan data dari kuesioner yang telah di isi oleh responden yang nantinya dibuat tabulasi data untuk memudahkan peneliti dalam membuat kesimpulan. Tahap terakhir yaitu menganalisis data dengan analisis univariat dan analisis bivariate sehingga mudah bagi pembaca untuk memahami hasil penelitian.

Kemenkes (2014) menyatakan bahwa untuk meningkatkan penyelenggaraan Komunikasi Data, dilakukan pengembangan Komunikasi Data yang mengacu pada analisis dan kajian meliputi pengembangan infrastruktur dan aplikasi, tenaga pengelola, prosedure penyelenggaraan, dan hal lain yang terkait. Pernyataan tersebut mendorong peneliti untuk melakukan analisis di Puskesmas Mojoagung dengan metode Technology Acceptance Model (TAM). Peneliti menggunakan metode tersebut karena SIMPUS di Puskesmas Mojoagung baru pertamakali dilakukan analisis, selain itu metode tersebut dapat menerima alasan atau penyebab dari penerimaan maupun kekurangan dalam sistem tersebut sehingga tetap digunakan meskipun banyak masalah yang masih terjadi. Serta dapat menghasilkan sebuah acuan untuk merancang perbaikan sistem dari beberapa kekurangan sistem supaya sistem dapat berjalan lebih baik lagi untuk kedepannya. TAM didasarkan pada Theory of Reasoned Action (TRA) dan digunakan untuk memaparkan penerimaan teknologi oleh seorang individu melalui kuesioner dan analisis selanjutnya. Technology Acceptance Model (TAM) muncul dengan dua konstruksi dasar yaitu Perceived Usefulness (PU) atau persepsi kemanfaatan dan Perceived easy of use (PEOU) atau persepsi kemudahan pengguna. Menurut Davis dalam Nunes (2018) mengatakan bahwa persepsi manfaat terjadi ketika seseorang menggunakan teknologi dengan tujuan meningkatkan kinerjanya, dan persepsi kemudahan penggunaan terjadi ketika seseorang berpikir bahwa teknologi itu mudah digunakan (Ana Nunes, 2018)

Berdasarkan analisis persepsi pengguna untuk mengetahui permasalahan dan kebutuhan pengguna dalam menjalankan system berdasarkan pengalaman mereka yang menggunakan. Permasalahan tersebut digunakan sebagai referensi dan kontrol untuk perubahan sistem selanjutnya, sehingga dapat menjadi masukan dalam pengembangan selanjutnya Sistem Informasi Manajemen Puskesmas (SIMPUS) di Puskesmas Mojoagung. Maka perlu dilakukan penelitian dengan tujuan menganalisis penerimaan Sistem Informasi Manajemen Puskesmas (SIMPUS) yang ditinjau dari persepsi pengguna dengan menggunakan metode Technology Acceptance Model (TAM) yang dilakukan di Puskesmas Mojoagung Kabupaten Jombang.

\section{METODE PENELITIAN}

Pelaksanaan penelitian ini secara umum terdiri dari 4 tahap seperti pada gambar 1. Pada tahap pertama yaitu mengidentifikasi permasalahan yang ada pada SIMPUS di Puskesmas Mojoagung. Tahap kedua yaitu penyusunan kuesioner mengacu pada indikator di masing-masing variabel. Tahap ketiga yaitu pengambilan data menggunakan kuesioner yang telah disebarkan kepada responden yaitu seluruh pengguna SIMPUS di Puskesmas Mojoagung. Tahap keempat yaitu mengidentifikasi penerimaan SIMPUS dan menganalisis hubungan antar kedua variabel sesuai dengan kerangka konsep pada TAM.

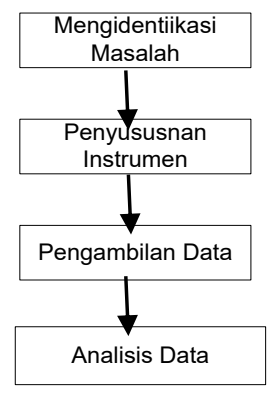

Gambar 1. Alur Penelitian

\subsection{Mengidentifikasi Masalah}

Mengidentifikasi masalah atau situasi yang terdapat pada SIMPUS di Puskesmas Mojoagung. Tahapan ini merupakan tahap awal atau tahap perencanaan. Tahap ini juga peneliti menemukan permasalahan dalam penggunaan SIMPUS, masalah yang ada didefinisikan dan dijelaskan pada penyusunan latar belakang.

\subsection{Penyusunan Instrumen}

Instrumen penelitian adalah alat yang dapat mendukung penelitian ini yaitu kuesioner. Instrumen dalam penelitian ini merupakan kuesioner yang digunakan untuk mengukur nilai variabel yang diteliti. Instrumen merupakan hal yang sangat penting di dalam kegiatan penelitian, karena instrumen penelitian adalah alat yang dapat mendukung sebuah penelitian. Hal tersebut dikarenakan perolehan suatu informasi atau data relevan atau tidaknya tergantung pada alat ukur tersebut. Menyusun sejumlah pernyataan tertulis yang berisi tentang persepsi pengguna sistem informasi puskesmas yang digunakan untuk memperoleh informasi dari responden dimana peneliti menyususnan butir-butir pernyataan pada kuesioner yang sesuai dengan variabel TAM sejumlah 12 pertanyaan yang akan digunakan dalam menganalisis penerimaan SIMPUS di Puskesmas Mojoagung. 


\subsection{Pengambilan Data}

Pengambilan data dilakukan dengan cara menyebarkan kuesioner kepada seluruh pengguna SIMPUS yang berjumlah 33 orang dengan menggunakan perhitungan sampel jenuh. Setelah data terkumpul, dilakukan pengolahan data meliputi kegiatan pengeditan data, informasi data, serta penyajian data sehingga diperoleh data yang lengkap dari masing-masing obyek untuk setiap variabel yang diteliti. Berikut kejelasan sampel pada penelitian ini :

Tabel 1. Jumlah Dan Jenis Petugas Pengguna SIMPUS

\begin{tabular}{lc}
\hline \multicolumn{1}{c}{ jenis tenaga kerja } & jumlah \\
\hline Perekam Medis & 2 \\
Petugas Pendaftraran Rawat Jalan & 3 \\
Petugas Laboratorium & 2 \\
Petugas Poli Umum & 2 \\
Petugas Poli Gigi & 1 \\
Petugas Poli KIA & 1 \\
Petugas Poli KB/IVA & 1 \\
Petugas Rawat Inap & 4 \\
Petugas Poli Mata & 1 \\
Petugas Poli Poned & 1 \\
Petugas UGD & 4 \\
Petugas Poli ANC (Bumil) & 1 \\
Petugas Gizi & 1 \\
Petugas Poli TB & 1 \\
Petugas PUSTU & 2 \\
Petugas POLINDES & 6 \\
& 33 \\
\hline
\end{tabular}

\subsection{Analisis Data}

Analisis yang digunakan dalam penelitian ini adalah analisis univariat dan analisis bivariate. Analiais univariat mengidentifikasi dengan mendeskripsikan setiap variabel menggunakan tabel distribusi frekuensi dan analisis bivariat yang berfungsi untuk melihat hubungan variabel independen dengan variabel dependen apakah variabel tersebut terdapat hubungan yang signifikan atau hanya hubungan secara kebetulan dengan menganalisis data dengan uji rank spearman yang didapat dari data pada hasil kuesioner menggunakan aplikasi komputer.

\section{KAJIAN PUSTAKA}

\subsection{Technology Acceptance Model (TAM)}

Technology Acceptance Model (TAM) adalah model penerimaan teknologi yang dikembangkan oleh Davis et al. (1989) berdasarkan model TRA. TAM berargumentasi bahwa penerimaan pengguna sistem terhadap sistem teknologi isnformasi yang digunakan di tentukan oleh dua kontruksi utama yaitu persepsi kemanfaatan (perceived usefulness) dan persepsi kemudahan (perceived easy of use) (Dalimunthe, 2013).

Mengetahui tingkatan penerimaan sistem informasi yang diterapkan di Pukesmas Mojoagung dapat dianalisis dengan metode TAM, untuk memahami sikap penerimaan pengguna terhadap hadirnya teknologi. Menurut Endang Fatmawati (2015) TAM adalah salah satu teori perilaku (behavioral theory) yang banyak digunakan untuk mengkaji suatu proses adopsi teknologi informasi. Tidak hanya memprediksi, namun juga harus bisa menjelaskan. Model TAM dan indikatornya memang sudah teruji dapat mengukur penerimaan teknologi, sehingga TAM akan mampu menjelaskan alasan sistem informasi Puskesmas Mojoagung bisa diterima dengan baik ataupun tidak oleh pengguna.

TAM biasa digunkaan untuk mengetahui tingkat penerimaan sistem informasi yang mudah untuk dilakukan analisis. TAM juga merupakan pisau analisis yang digunkan untuk mengetahui tenang sikap penerimaan pengguna terhadap hadirnya teknologi. Sebelum TAM muncul, terdapat teori yang dikenal dengan nama Theory Of Reasoned Action (TRA) yang dikembangkan oleh Martin Fishbein dan Icek Ajzen (1975, 1980). Selanjutnya pada tahun 1980 Davis melakukan penelitian sehingga memunculkan teori TAM dengan penekanan pada persepsi kemudahan penggunaan dan kebermanfaatan yang memiliki hubungan untuk memprediksi sikap dalam menggunakan sistem informasi. TAM dan indikatornya memang sudah teruji dapat mengukur penerimaan teknologi. Dengan demikian menggunakan TAM maka akan mampu menjelaskan mengapa SIMPUS di Puskesman Mojoagung bisa diterima atau tidak oleh pengguna (Fatmawati, 2015).

Widodo and Maimunah (2009) mengatakan bahwa model TAM dapat menjelaskan tentang penerimaan teknologi informasi (TI) yang bisa mempengaruhi penerimaan teknologi oleh pengguna dengan variable-variabel tertentu. TAM memiliki variabel kebermanfaatan dan kemudahan yang dapat mempengaruhi penggunaan sistem (actual system use) melalui sebuah variabel intervening yakni intensitas penggunaan (behavioural intention to use). Akan tetapi pada penelitian Arif Surachman (2008) mengatakan bahwa menurut Gahtani (2000) dalam Oktavianti (2007) menjelaskan bahwasannya intensitas penggunaan dan penggunaan sistem dapat digantikan oleh variabel penerimaan terhadap TI (Acceptance of IT). Sehingga model yang peneliti gunakan dalam penelitian ini adalah sebagai Gambar 2.

Skema tersebut diketahui bahwa terdapat dua faktor utama yang dapat mempengaruhi penerimaan terhadap teknologi yaitu faktor kebermanfaatan dan faktor kemudahan. Model skema tersebut diadopsi dari model TAM Davis (1989) dan Oktavianti (2007). 


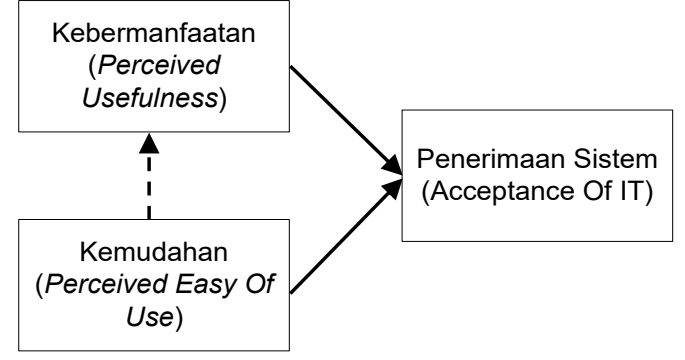

Gambar 2. Technologi Acceptance Model (TAM) (Model Davis (1989) dan Oktavianti (2007))

\subsubsection{Perceived Usefulness (PU) Atau Persepsi Kemanfaatan}

Persepsi kemanfaatan penggunaan dapat diartikan sebagai kepercayaan yang dimiliki pengguna bahwa jika menggunakan teknologi tersebut dapat meringankan beban performa dalam bekerja. Jika pengguna telah merasa percaya bahwa sistem informasi berguna maka akan menggunakannya. Sebaliknya jika seseorang merasa percaya bahwa sistem informasi kurang beguna maka dia tidak akan menggunakannya. Pengukuran kontruksi kemanfaatan terdiri dari:

1. Menjadikan pekerjaan lebih cepat

2. Bermanfaat

3. Menambah produktifitas

4. Mempertinggi efektifitas

5. Mengembangkan kinerja pekerja

6. Manfaat

\subsubsection{Perceived Easy Of Use (PEOU) atau Persepsi Kemudahan Pengguna}

Persepsi kemudahan penggunan dari suatu teknologi mengarah kepada kepercayaan yang dimiliki oleh pengguna bahwasannya jika menggunakan teknologi tidak akan membutuhkan usaha lebih (mudah digunakan). Meskipun pendapat orang tentang usaha berbeda-beda tetapi pada umumnya untuk meminimalisir penolakan dari pengguna sistem atas sistem yang dikembangkan, maka sistem harus mudah digunkan oleh pengguna tanpa mengeluarkan usaha besar. Berikut ini beberapa indikator konstruksi kemudahan yaitu:
1. Kemudahan untuk dipelajari
2. Kemudahan mencapai tujuan
3. Jelas dan mudah dipahami
4. Fleksibel
5. Bebas dari kesulitan
6. Kemudahan penggunaan (Suryanti, 2017)

\subsection{Sampel Jenuh}

Sampel adalah bagian dari jumlah dan karakteristik yang dimiliki oleh populasi tersebut. Teknik pengambilan sampel menggunakan Sampling Jenuh yaitu teknik penentuan sampel dengan semua populasi yang digunakan sebagai sampel. Hal ini dilakukan karena jumlah populasi relatif kecil (Sugiyono, 2016).

\section{HASIL DAN PEMBAHASAN}

4.1 Mengidentifikasi Penerimaan Sistem Informasi Manajemen Puskesmas (SIMPUS) Ditinjau Dari Persepsi Pengguna Di Puskesmas Mojoagung Dengan Metode Technology Acceptance Model (TAM).

Identifikasi adalah proses pengenalan, menempatkan obyek atau individu dalam suatu kelas sesuai dengan karakteristik tertentu. Penelitian ini menghasilkan identifikasi pada variabel yang ada pada Technology Acceptance Model (TAM). Variabel yang akan diidentifikasi adalah Perceived Usefulness dan Perceived Easy Of Uses
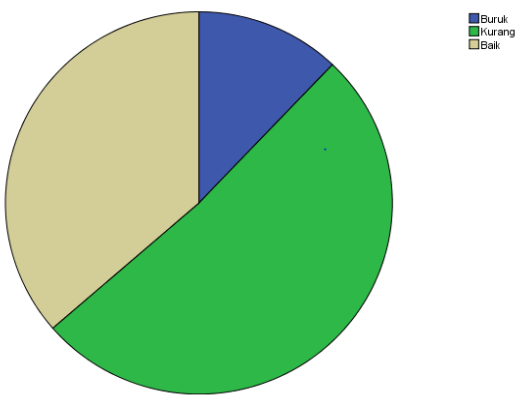

Gambar 3. Perceived Usefulness (Persepsi Kemanfaatan)

Dapat dilihat dari Gambar 3 dapat diketahui bahwa hasil rekapitulasi pada perceived usefulness (persepsi kemanfaatan) pengguna SIMPUS diketahui bahwa 4 atau (12.1\%) dari total responden memiliki persepsi kemanfaatan SIMPUS dalam kategori buruk, 17 atau (51.5\%) dari total responden memiliki persepsi kemanfaatan SIMPUS dalam kategori kurang dan 12 atau (36.4\%) dari total responden memiliki persepsi kemanfaatan SIMPUS dalam kategori baik. Hasil identifikasi yang didapatkan persentase tertinggi terdapat pada kategori kurang yakni penggunaan SIMPUS cukup bermanfaat dikarenakan SIMPUS masih dapat membantu kinerja petugas, meskipun tidak semua fitur yang ada dalam SIMPUS bermanfaat bagi pengguna seperti fitur pelaporan yang tidak digunakan. SIMPUS juga tidak dapat mencetak formulir pendaftaran secara langsung sehingga harus menyalin data pada SIMPUS lalu diletakkan pada Ms. Excel dan di print. Dalam penggunaan SIMPUS di Puskesmas Mojoagung, Puskesmas juga masih menggunakan berkas yang isi pada berkas tersebut lebih lengkap dari pada data yang di inputkan ke dalam SIMPUS. Hal tersebut terjadi karena SIMPUS belum dapat memberikan kebutuhan pengguna dengan baik. Ketidak bermanfaatan SIMPUS pada beberapa hal seharusnya dibenahi dengan menganalisis kebutuhan pengguna sehingga segala fitur dapat dimanfaatkan dengan baik tanpa menghilangkan fitur yang sudah bermanfaat. 


\section{Jurnal Teknologi Informasi dan Ilmu Komputer (JTIIK), Vol. 8, No. 1, Februari 2021, hlm. 47-54}

Persepsi kemanfaatan penggunaan dimaknai sebagai kepercayaan pengguna terhadap teknologi apabila dengan menggunakan teknologi tersebut dapat membantu meringankan performa dalam bekerja. (Widodo, 2009). Pembuatan pelaporan masih terdapat pelaporan yang dilakukan secara manual karena pelaporan yang di minta Dinas Kesehatan Jombang belum dapat terpenuhi oleh SIMPUS Jombang, permintaan pelaporan yang Dinas Kesehatan minta adalah dibedakan anatar pasien BPJS dan pasien UMUM, sedangkan SIMPUS hanya dapat menampilkan pelaporan secara umum. Begitu juga dengan formulir yang dicetak harus melakukan dua kali kerja serta masih mengandalkan kertas untuk berkas rekam medis dalam operasionalnya hal tersebut mengharuskan pihak puskesmas untuk membuat melakukan pekerjaan secara manual dan elektronik.

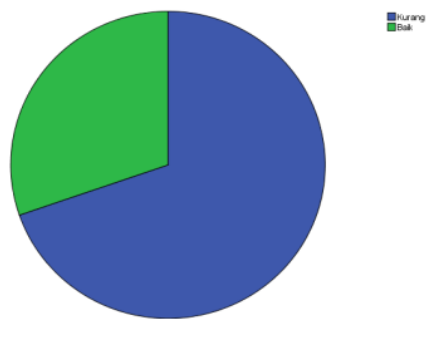

Gambar 4. Perceived Easy Of Use (Persepsi Kemudahan)

Berdasarkan Gambar 4 dapat diketahui bahwa hasil rekapitulasi pada perceived easy of use (persepsi kemudahan) pengguna SIMPUS diketahui bahwa 23 atau $(69.7 \%)$ dari total responden memiliki persepsi kemudahan SIMPUS dalam kategori kurang dan 10 atau (30.3\%) dari total responden memiliki persepsi kemudahan SIMPUS dalam kategori baik. Hasil identifikasi yang didapatkan persentase tertinggi terdapat pada kategori kurang yakni penggunaan SIMPUS masih memberikan dampak kemudahan. Akan tetapi dampak yang ditimbulakan dengan tidak adanya menu bantuan pada aplikasi cukup bermasalah dalam penggunaan SIMPUS kerena mrngharuskan kepala rekam medis puskesmas yang dapat menanganinya. Setiap adanya pelatihan atau sosialisasi di Jombang tentang penggunaan SIMPUS, hanya kepala rekam medis yang mengikutinya. SIMPUS yang sering mengalami error yang disebabkan oleh kesalahan jaringan mengaakibatkan seluruh komputer dan leptop di Puskesmas Mojoagung tidak dapat digunakan. Hal tersebut mengharuskan pengguna untuk menunda pengimputan data pasien dan akhirnya berkas menumpuk. Selain hal tersebut, saat terjadi error, SIMPUS dapat menyimpan data yang belum terisi dan mengakibatkan duplikasi data. SIMPUS tidak dapat mengontrol hak akses pengguna karena hanya memiliki satu username dan password yang digunakan untuk seluruh petugas di Puskesmas Mojoagung.

Persepsi kemudahan penggunan dari suatu teknologi dapat dilihat pada kepercayaan pengguna bahwa teknologi tersebut mudah digunakan, hal tersebut menghindari penolakan dari pengguna sistem pada sistem yang dikembangkan, maka sistem harus mudah digunkaan tanpa memberatkan penggunanya (Suryanti, 2017). Pemahaman SIMPUS tidak semua pengguna SIMPUS memahami menu yang ada pada SIMPUS dengan baik dikarenakan dalam Aplikasi SIMPUS tidak terdapat menu bantuan untuk memahami penggunaan SIMPUS sehingga ketika terjadi kesalahan sistem maka Kepala Rekam Medis yang menanganinya. Pengguna hanya memahami apa yang harus di input dan disimpan tanpa memahami segala isi yang ada di SIMPUS, sehingga ketika terdapat pengguna baru maupun magang atau pengguna lain yang kurang memahan SIMPUS hanya bias bertanya kepada Kepala Rekam Medis karena hanya Kepala Rekam Medis yang mengikuti pelatihan. Duplikasi dan kendala penginputan berkas serta dalam mengontrol hak akses guna menangani tanggung jawab untuk kesalahan yang terjadi yang mengakibatkan menurunnya mutu puskesmas belum dapat diatasi.

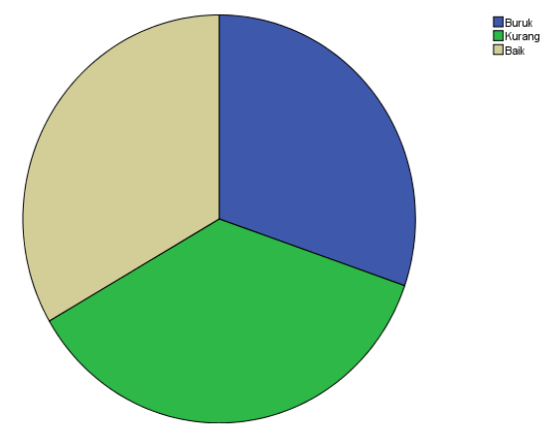

Gambar 5. Penerimaan Sistem

Berdasarkan Gambar 5 dapat diketahui bahwa hasil rekapitulasi pada persepsi dalam penerimaan sistem diketahui bahwa 10 atau $(30.3 \%)$ dari total responden memiliki persepsi dalam penerimaan sistem masuk pada kategori buruk, 12 atau (36.4\%) dari total responden memiliki persepsi dalam penerimaan sistem masuk pada kategori kurang dan 11 atau $(33.3 \%)$ dari total responden memiliki persepsi dalam penerimaan sistem masuk pada kategori baik. Hasil identifikasi yang didapatkan persentase tertinggi terdapat pada kategori kurang yakni SIMPUS dapat menyediakan beberapa layanan yang diinginkan pengguna sehingga SIMPUS di Puskesmas Mojoagung memberikan pengaruh keuntungan dan merupakan hal yang wajib ataupun tunutan yang harus dijalankan dari Dinas Kesehatan Jombang.

Persepsi pengguna Teknologi Informasi (TI) daapat mempengaruhi sikap dalam penerimaan 
terhadap teknologi. Selain itu dapat menjelaskan tentang pertimbangan penerimaan komputer secara umum dan menjelaskan tentang perilaku atau sikap pengguna dalam suatu populasi (Davis et.al., 1989). SIMPUS dapat menyediakan beberapa layanan yang dibutuhkan dan telah sesuai dengan masing-masing pengguna sehingga SIMPUS di Puskesmas Mojoagung dapat diterima dan di gunakan. Selain itu, Dinas Kesehatan Jombang juga mengharuskan seluruh puskesmas di Jombang untuk menerima penggunaan SIMPUS meskipun minimalnya sumber daya yang tersedia.

\subsection{Menganalisis Hubungan Sistem Informasi Manajemen Puskesmas (SIMPUS) Ditinjau Dari Persepsi Pengguna Di Puskesmas Mojoagung Dengan Metode Technology Acceptance Model (TAM).}

Menganasisis hubungan antara variabel perceived usefulness (persepsi kemanfaatan) dengan penerimaan sistem dan menganasisis hubungan anatara variabel perceived easy of use (persepsi kemudahan) dengan penerimaan sistem. Analisis yang dilakukan adalah melihat signifikansi pada hasil perhitungan pada aplikasi komputer dan dibadingkan dengan nilai p-value (Sig.) yang telah ditentukan yaitu 0.05 , melihat kekuatan hubungan dari kategori sangat lemah sampai ketegori sempurna dan melihat arah hubungan yaitu positif yang artinya hubungan searah dan negatif yang artinya hubungan tidak.

Dilihat dari Tabel 2 dapat diketahui bahwasannya nilai signifikansi yang didapat bernilai lebih kecil dari p-value (Sig.) yaitu 0.031 artinya ada hubungan yang signifikasn antara variabel perceived usefulness (persepsi kemanfaatan) dengan penerimaan sistem. Oleh sebab itu $\mathrm{H}_{1}$ diterima yang artinya memang benar terdapat perceived usefulness (persepsi kemanfaatan) dalam penerimaan sistem, maksudnya adalah ada persepsi kemanfaatan dari pengguna SIMPUS sehingga SIMPUS tersebut diterima di Puskesmas Mojoagung. Beberapa hal yang mempengaruhi penerimaan sistem dilihat dari persepsi pengguna SIMPUS terkait dengan kinerja SIMPUS yang masih membantu petugas ketika menginputkan data, penginputan data dapat meningkatkan produktifitas kerja serta lebih cepat daripada pencatatan secara manual.

\begin{tabular}{|c|c|c|c|}
\hline hipotesis & variabel & $\begin{array}{l}\text { correlation } \\
\text { coefficient }\end{array}$ & $\begin{array}{l}\text { nilai } \\
\text { sign. }\end{array}$ \\
\hline H1 & $\begin{array}{c}\text { Hubungan } \\
\text { Perceived } \\
\text { Usefulnes dengan } \\
\text { Penerimaan } \\
\text { Sistem }\end{array}$ & $0.377^{\prime}$ & 0.031 \\
\hline $\mathrm{H} 2$ & $\begin{array}{c}\text { Hubungan } \\
\text { Perceived Easy Of } \\
\text { Use dengan } \\
\text { Penerimaan } \\
\text { Sistem }\end{array}$ & $0.430^{\prime}$ & 0.012 \\
\hline
\end{tabular}

Selanjutnya, didapatkan angka koefisien korelasi yaitu $0.377^{\prime}$, artinya tingkat kekuatan hubungan antara variabel perceived usefulness (persepsi kemanfaatan) dengan penerimaan sistem adalah 0.377'atau rendah. Angka korelasi pada tersebut memiliki nilai positif, yaitu 0.377 'sehingga hubungan antar kedua variabel tersebut memiliki jenis hubungan searah. Dengan demikian dapat dijelaskan bahwasannya persepsi kemanfaatan semakin ditingkat maka peneriman sistem juga akan meningkat.

Hasil penelitian ini juga didukung oleh penelitian Saputra (2013) bahwa kemudahan penggunaan teknologi informasi SIMRS berpengaruh positif. Selain itu hasil juga menunjukkan signifikansi terhadap kemanfaatan teknologi informasi dengan hal ini hipotesis dalam penelitian tersebut diterima.

Berdasarkan hasil tersebut dapat dijelaskan bahwa ketika Dinas Kesehatan Jombang sering melakukan perbaikan pada SIMPUS Jombang, maka semakin bermanfaatlah SIMPUS tersebut bagi pengguna sehingga SIMPUS Jombang selalu diterima dalam penerapannya. Perbaikan kemanfaatan didasarkan pada kebutuhan pengguna SIMPUS sehingga lebih memudahkan dalam memaksimalkan kemanfaatan SIMPUS. Maka dari itu, untuk mengetahui kebutuhan pengguna harus diadakan pertemuan sehingga dapat mengetahui kekurangan dan kelebihan serta hal yang harus diperbaiki dari SIMPUS.

Dilihat pada Tabel 2 juga dapat diketahui bahwasannya nilai signifikansi yang didapat bernilai lebih kecil dari p-value (Sig.) yaitu 0.012 artinya ada hubungan yang signifikansi antara variabel perceived easy of use (persepsi kemudahan) dengan penerimaan sistem. Oleh sebab itu $\mathrm{H} 2$ diterima yang artinya memang benar terdapat perceived easy of use (persepsi kemudahan) dalam penerimaan sistem, maksudnya adalah ada persepsi kemudahan dari pengguna SIMPUS sehingga SIMPUS tersebut diterima di Puskesmas Mojoagung. Dalam hal ini penerimaan sistem dipengaruhi oleh persepsi kemudahan yaitu SIMPUS mampu memudahkan pengguna dalam mencari data pasien yang tersimpan dalam database. Sehingga pencarian berkas lebih mudah dengan diterapkannya SIMPUS di Puskesmas Mojoagung. Selanjutnya didapat angka koefisien korelasi sebesar 0.430 ', artinya tingkat kekuatan hubungan antara variabel perceived easy of use (persepsi kemudahan) dengan penerimaan sistem adalah 0.430 ' atau sedang. Angka korelasi pada hasil tersebut memiliki nilai yang positif, yaitu 0.430 ' sehingga hubungan kedua variabel tersebut bersifat searah. Dengan demikian dapat diartikan bahwa persepsi kemudahan semakin meningkat maka penerimaan sistem juga akan meningkat.

Hasil penelitian diatas juga didukung oleh penelitian Sayekti and Putarta (2016) tentang penggunaan Sistem Informasi Pengelolaan 
Keuangan Daerah (SIPKD) yang menyatakan bahwa variabel perceived easy of use (persepsi kemudahan) dan perceived usefulness (persepsi kemanfaatan) mempengaruhi penggunaan SIPKD, dalam artian bahwa user memiliki persepsi bahwa SIPKD mudah digunakan dan bermanfaat maka user menerima SIPKD dan diharapkan termotivasi untuk mempelajari dan menggunakan SIPKD.

Berdasarkan hasil tersebut dapat dijelaskan bahwa ketika Dinas Kesehatan Jombang sering melakukan perbaikan pada SIMPUS Jombang dan juga pelatihan pada penggunanya disertakan terdapat panduan dalam aplikasi, maka semakin mudahlah SIMPUS tersebut digunakan oleh pengguna sehingga SIMPUS Jombang selalu diterima dalam penerapannya.

\section{KESIMPULAN}

Berdasarkan identifikasi di dapat total responden yang memiliki nilai persentase tertinggi dalam kategori buruk terdapat pada variabel penerimaan sistem yaitu 10 atau $30.3 \%$ responden dan nilai persentase terendah terdapat pada variabel perceived easy of use yaitu 0 atau $0 \%$. Nilai persentasse tertinggi pada kategori kurang berada pada variabel perceived easy of use yaitu 23 atau $69.7 \%$ responden dan nilai persentase terendah dalam kategori kurang berada pada variabel penerimaan sistem. Persentase nilai tertinggi pada kategori baik terdapat pada variabel perceived usefulness yaitu 12 atau $36.4 \%$ responden dan nilai persentase terendah pada kategori baik terdapat pada variabel perceived easy of use yaitu 10 atau $30.3 \%$. Nilai ambang kategori penilaian buruk yaitu $0 \%$ dengan 0 responden dan nilai ambang kategori baik yaitu $100 \%$ dengan 33 responden.

Berdasarkan perceived usefulness (persepsi kemanfaatan) di dapat H1 diterima, ada hubungan yang signifikasnsi antara variabel perceived usefulness (persepsi kemanfaatan) dengan penerimaan sistem dengan nilai signifikansi yang didapat bernilai lebih kecil dari p-value (Sig.) yaitu 0.031. Berdasarkan perceived easy of use (persepsi kemudahan) di dapat $\mathrm{H} 2$ diterima, ada hubungan yang signifikasnsi antara variabel perceived easy of use (persepsi kemudahan) dengan penerimaan sistem dengan nilai signifikansi yang didapat bernilai lebih kecil dari p-value (Sig.) yaitu 0.012 .

\section{DAFTAR PUSTAKA}

NUNES, A. F. P. and M. F. S., 2018. Improving Pervasive Decision Support System in Critical Care by using Tecnology Acceptance Model. Computer Science, 141, pp. 513-518.

DALIMUNTHE, N. H. W., 2013. Analisis Penerimaan Sistem e-learning SMK Labor Pekanbaru Dengan Menggunakan
Technology Acceptance Model (TAM). Jurnal Sains dan Teknologi Industri, 11(1), doi: 10.1002/ejoc.201200111.

FATMAWATI, E., 2015. Technology Acceptance Model (TAM) Untuk Menganalisis Penerimaan Terhadap Sistem Informasi Perpustakaan. Jurnal iqra', 09(1), pp. 1-11.

Peraturan Menteri Kesehatan Indonesia No. 75 tahun 2014 Tentang Pusat Kesehatan Masyarakat. Jakarta: Kementrian Kesehatan Republik Indonesia.

Peraturan Menteri Kesehatan Indonesia No. 92 tahun 2014 Tentang Penyelenggaraan Komunikasi Data dalam Sistem Informasi Kesehatan Terintegrasi. Jakarta: Kementrian Kesehatan Republik Indonesia.

SAPUTRA, E. M., 2013. Analisis Penerimaan Sistem Informasi Manajemen Rumah Sakit Umum Daerah Bangkinang Menggunakan Metode Technology Acceptance Model (TAM). Jurnal Sains dan Teknologi Industri, 10(2), pp. 1-7.

SAYEKTI, F. dan PUTARTA, P., 2016. Penerapan Technology Acceptance Model (TAM) Dalam Pengujian Model Penerimaan Sistem Informasi Keuangan Daerah. Jurnal Manajemen Teori dan Terapan, 9(3), pp. 196-209.

SUGIYONO, 2016. Metode Penelitian Kuantitatif, Kualitatif, Dan R\&D. [Offline]. Tersedia di: Perpustakaan Politeknik Negeri Jember $<$ https://perpustakaan.polije.ac.id/>.

SURYANTI, 2017. Evaluasi Aplikasi Primary Care (P-Care) Dengan Menggunakan Metode TAM (Technology Acceptance Model) Pada Puskesmas Kraton Kabupaten Pasuruan. [Offline]. Skripsi. Tersedia di: Perpustakaan Politeknik Negeri Jember $<$ https://perpustakaan.polije.ac.id/>.

THENU, V. J., SEDIYONO, E. dan PURNAMI, C. T., 2016. Evaluasi Sistem Informasi Manajemen Puskesmas Guna Mendukung Penerapan Sikda Generik Menggunakan Metode Hot Fit Di Kabupaten Purworejo. Jurnal Manajemen Kesehatan Indonesia, 4(2), pp. 129-138. doi: 10.14710/JMKI.4.2.2016.129-138.

WIDODO, P. dan MAIMUNAH, H., 2009. Kajian Persepsi Pengguna Teknologi Pembelajaran Raharja Multimedia Edutainment (RME) Menggunakan Metode Technology Acceptance Model. CCIT Journal, 2(3), pp. 231-256. Tersedia pada: $<$ http://raharja.ac.id $>$ [Diakses pada 12 Oktober 2019]. 